\title{
Gambaran pelaksanaan program penanganan kekerasan terhadap perempuan dan anak pada Puskesmas di Yogyakarta
}

\author{
Rosmita Nuzuliana, ${ }^{1 *}$ Siti Istiyati ${ }^{2}$ \\ 1, 2Universitas 'Aisyiyah Yogyakarta - Indonesia
}

\begin{abstract}
The problem of violence against women and children $(\mathrm{VaW} / \mathrm{C})$ is a problem that requires special attention, because cases of $\mathrm{VaW} / \mathrm{C}$ are increasing every year. The purpose of this study was to determine the description of the management of cases of violence against children and women in Yogyakarta City Health Center. The design of this study was qualitative with data collection using indept interviews, the KtP / A Program Coordinator, and the implementing midwife as research subjects. Data triangulation with Psychologists and Program Coordinators and the Integrated Service Center for the Protection of Women and Children with indept interviews. The results of this study found that the implementation of VaW/C handling was not optimal. This is because extracting cases of violence is obtained when patients arrive, and not conducting surveys to the community. this is because the VaW/C program is not a priority for the Puskesmas work program. Violence prevention activities are carried out by socializing to the community. The facilities and infrastructure for handling cases of violence are adequate but do not have separate rooms. The implementation of VaW/C handling is in the form of physical examination and counseling. Suggestions for Puskesmas are to develop and optimize programs for handling $\mathrm{VaW} / \mathrm{C}$ so that cases of $\mathrm{VaW} / \mathrm{C}$ can be revealed and handled.
\end{abstract}

Keywords: violence; women; children

\begin{abstract}
Masalah kekerasan terhadap perempuan dan anak (KtP/A) merupakan masalah yang membutuhkan perhatian khusus, karena kasus KtP/A meningkat setiap tahun. Tujuan penelitian ini adalah untuk mengetahui gambaran tatalaksana (penanganan) kasus kekerasan pada anak dan perempuan di Puskesmas Kota Yogyakarta. Rancangan penelitian ini kualitatif dengan pengambilan data adalah indept interview, Koordinator Program KtP/A, dan bidan pelaksana sebagai subjek penelitian. Triangulasi data dengan psikolog dan koordinator program dan pihak Pusat Pelayanan Terpadu Perlidungan Perempuan dan Anak (P2TP2A) dengan indept interview. Hasil penelitian ini didapatkan pelaksanaan penanganan KtP/A belum optimal. Hal ini disebabkan penggalian kasus kekerasan didapatkan ketika pasien datang, dan tidak melakukan survey kepada masyarakat. hal ini disebabkan Program KtP/A bukan merupakan prioritas program kerja Puskesmas. Kegiatan pencegahan kekerasan dilakukan dengan sosialisasi kepada masyarakat. Sarana dan prasarana dalam penanaganan kasus kekerasa $\mathrm{n}$ mayoritas memadai namun belum memiliki ruangan terpisah. Pelaksanaan penangaan KtP/A berupa pemeriksaan fisik dan konseling. Saran untuk Puskesmas mengembangkan dan mengoptimalkan program penanganan KtP/A sehingga kasus KtP/A bisa terungkap dan tertangani.
\end{abstract}

Kata Kunci: kekerasan; perempuan; anak

"Korespondensi Penulis: Rosmita Nuzuliana (email: rosmitanz@unisayogya.ac.id), Mlangi Nogotirto, Jl. Siliwangi, Jl. Ringroad Barat No. 63, Gamping, Sleman, Daerah Istimewa Yogyakarta 55592. 


\section{Pendahuluan}

Kekerasan pada anak dan perempuan merupakan permasalahan yang kasusnya mengalami peningkatan dari tahun ke tahun, bahkan mendapat perhatian baik secara nasional dan internasional.

Komisi Perlindungan Anak Indonesia (KPAI) melansir data tingkat kekerasan seksual anak selama 2019. Ada 21 kasus kekerasan seksual dengan korban mencapai 123 anak yang terjadi di institusi pendidikan. Komisioner KPAI Bidang Pendidikan Retno Listyarti melalui keterangan tertulis yang dilansir Antara di Jakarta menyatakan, "Korban mencapai 123 anak, terdiri atas 71 anak perempuan dan 52 anak laki-laki," (Moerti, 2019). Menurut catatatan tahunan Komnas Perempuan 2020, pada tahun 2019 terdapat Kekerasan terhadap Anak/Perempuan (KtA/P) melonjak sebanyak 2.341 kasus, tahun sebelumnya sebanyak 1.417 . Kenaikan dari tahun sebelumnya terjadi sebanyak $65 \%$ dan paling banyak adalah kasus inses dan ditambahkan dengan kasus kekerasan seksual (571 kasus) (Amiruddin et al., 2020).

Lebih spesifik, Wakil Ketua LPSK, Antonius Prijadi Soesilo Wibowo menjelaskan, sedikitnya ada 60 kasus yang tercatat dari data yang masuk ke Dinas Sosial di Kabupaten Kulon Progo, Gunungkidul, Sleman, dan Bantul (Ismiyanto \& Nugroho, 2019).

Banyaknya kasus kekerasan pada anak dan perempan ini menimbulkan dampak secara fisik, psikis dan sosial. Korban kekerasan akan mengalami trauma yang mendalam, ketakutan, stress dan menarik pergaulan dari masyarakat. Penyebab kekerasan pada perempuan ini diantara- nya adalah 56\% kekerasan oleh suami (KDRT), 21\% kekerasan pada pacaran, 17\% kekerasan pada anak dan perempuan dan sisanya kekerasan oleh mantan suami, mantan pacar dan oleh majikan (Komnas Perempuan, 2017). Penyebab kekerasan paling banyak terjadi di lingkungan keluarga 20,35\%, yang mana hubungan keluarga dengan korban $27 \%$ ayah kandung, dan 25\% ibu kandung (KPAl, 2020).

Bentuk kekerasan lain adalah kekerasan fisik, kekerasan psikis, inses, kekerasan seksual dan ekonomi (Amiruddin et al., 2020). Peningkatan ini terjadi karena: 1) lemahnya kontrol pengendalian belanja harian rumah tangga, yang lebih mengutamakan kebutuhan tersier seperi pulsa, bensin, dan rokok dari pada pemenuhan kebutuhan primer, 2) terjadinya konstriksi gender yang mengatakan cantik itu identik dengan langsing dan lain sebagainya, 3) rendahnya pola komunikasi keluarga yang tidak terbuka antara orang tua dan anak (BPPM DIY, 2016).

Daerah Istimewa Yogyakarta (DIY) merupakan salah satu provinsi di Indonesia yang memiliki masyarakat heterogen. Banyak penduduk yang datang dari daerah lain untuk berdomisili di provinsi ini, sehingga kearifan lokal harus selalu dipertahankan. Banyaknya pendatang di DIY menjadikan kota yang berpotensi dan rawan akan terjadinya kekerasan terutama pada anak dan perempuan. Data KPAI (2020) menyebutkan bahwa kasus kekerasan pada anak dan perempuan di DIY mencapai angka 1210 kasus.

Meningkatnya angka kekerasan pada perempuan dan anak (KtP/A) yang terjadi pada tahun 2009, Pemerintah Indonesia melalui Dinas Kesehatan, mencanangkan program "Puskesmas Mampu Tatalaksana Kasus Kekerasan terhadap 
Perempuan dan Anak." Tujuan pencanangan program ini sebagai langkah antisipatif karena kasus kekerasan di masyarakat khususnya kekerasan terhadap perempuan dan anak cenderung meningkat. Upaya Pemerintah dalam keberlanjutan dan optimalisasi program dengan kebijakan yang tertuang pada Peraturan Menteri Kesehatan Republik Indonesia Nomor 68 Tahun 2013 pada bab $\mathrm{V}$ tentang pembinaan dan pengawasan Pemerintah terhadap tempat pelayanan kesehatan bagi korban kekerasan pada anak dan perempuan.

Kasus kekerasan terhadap perempuan dan anak sangat mempengaruhi kesehatan yang berdampak pada penurunan kualitas Sumber Daya Manusia (SDM). Oleh karena itu dibutuhkan pelayanan kesehatan secara komprehensif dan berkualitas (Kemenkes Rl, 2009). Dalam memberikan pelayanan kesehatan pada kasus kekerasan terhadap anak, Pemerintah DIY melalui Dinas Kesehatan Kota Yogyakarta dibawahi oleh Dinas Kesehatan DIY, maka seluruh Puskesmas di Kota Yogyakarta dibekali ketrampilan dalam bentuk pelatihan penanganan korban kekerasan baik kekerasan perempuan maupun kekerasan pada anak. Program ini sudah dicanangkan sejak tahun 2006 dan berbagai implementasi telah dilakukan. (BPPM DIY, 2016).

\section{Metode}

Penelitian ini menggunakan rancangan kualitatif dengan metode pengambilan data dengan indept interview, dan studi dokumentasi. Indept interview digunakan untuk mengetahui sejauhmana penatalaksanaan penanangan kasus kekerasan pada anak, sedangkan studi dokumentasi menjawab jumlah kasus yang ada dan dilaporkan ke Dinas Kesehatan. Penelitian ini diawali dengan mengurus perijinan melalui Dinas Kesehatan dan dinas Perijinan Kota Yogyakarta serta kepala Puskesmas tempat penelitan. Penentuan informan didasarkan pada hasil identifikasi dan rekomendasi dari Puskesmas mengenai bagian yang mengurus masalah kekerasan pada anak dan perempuan. informan pada penelitian ini adalah Koordinator Program KtP/A, dan Bidan Pelaksana, di Puskesmas Mantrijeron, Umbulharjo I dan Mergangsan.

Konsistensi data penelitian ini menggunakan triangulasi data, dengan psikolog masing-masing Puskesmas dan Koordinator Program dan Pihak Pusat Pelayanan Terpadu Perlidungan Perempuan dan Anak (P2TP2A). Kegiatan triangulasi data ini dilakukan secara indept interview. Pengambilan data masing-masing Puskemas memerlukan kurang lebih 2-3 hari, hal ini dikarenakan tidak semua petugas kesehatan yang digunakan sebagai subjek penelitian dan triangulasi data berada di tempat dan waktu yang bersamaan. Data yang sudah terkumpul dianalisis dengan cara mereduksi data, menyajikan data dan menyimpulkan kedalam laporan penelitian. Oleh kedua peneliti dengan apersepsi pemahaman wawancara dan pengambilan data terlebih dahulu.

\section{Hasil dan Pembahasan}

\section{Cara pengumpulan data dan informasi terkait dengan kekerasan anak}

Hasil wawancara ketiga Puskesmas dalam pengumplan data didapatkan bahwa Puskesmas jarang melakukan identifikasi ke wilayah secara mandiri dan secara langsung ke pihak korban. 
"Kalau di sini kita kan lintas program ... ya kita kan saling komprehensif Ibu. Kalau misalnya kita menemukan kasus kekerasan pada anak kita langsung mengarahkan ke BPU mungkn di sana sudah ada dokternya dan sudah ada Mbak koordinator KtP/A yang bertanggung jawab. Karena kadang pasien itu langsung ke sana atau lagsung ke KIA kadang ke psikolog" (R1, W1).

Informan kedua pun mengatakan hal yang sama.

"Kalau ada kekerasan akan dirujuk ke psikolog, jika ada kekerasan fisik akan dilakukan pengobatan di BPU saja. Pihak Puskesmas tidak melakukan jemput bola, jika ada permasalahan di wilayah, kader sebagai tangan panjang Puskesmas enggan memberikan informasi ke pihak Puskemas. Seolah menutup-nutupi" (R2, W1).

"tapi nek data yang kekerasan pada anak hanya beberapa gak banyak, tapi mungkin di tempat psikolog juga ada, soale Mbak psikolog kadang itu kadang sok muter sendiri itu, kadang ada yang langsung konsultasi dan dia langsung terjun. Saya kadang ming dilapori jadi ini anu lho buk. Tapi datanya ada di sana" (N1, W1).

Hasil identifikasi didapatkan bahwa, data KtP/A mayoritas didapatkan dari korban yang datang langsung ke Puskesmas. Pihak Puskesmas jarang melakukan identifikasi atau deteksi dini kasus kekerasan di wilayah.

Tabel 1. Karakteristik Subjek Penelitian

\begin{tabular}{|c|c|c|c|}
\hline Subjek & Puskesmas Umbulharjo I & Puskesmas Mergangsan & Puskesmas Mantrijeron \\
\hline Bidan & $\begin{array}{l}\text { Bidan yang berlatar } \\
\text { belakang D3 Kebidanan } \\
\text { yang sering mengani kasus } \\
\text { kekersan pada perempuan } \\
\text { terutama pada kehamilan } \\
\text { tidak diinginkan (lama } \\
\text { bekerja } 20 \text { tahun). }\end{array}$ & $\begin{array}{l}\text { Bidan yang berlatar } \\
\text { belakang D3 Kebidanan } \\
\text { (lama bekerja } 18 \text { tahun). }\end{array}$ & $\begin{array}{l}\text { Bidan yang berlatar belakang } \\
\text { D3 Kebidanan yang sering } \\
\text { mengani kasus kekersan pada } \\
\text { perempuan terutama pada } \\
\text { kehamilan tidak diinginkan } \\
\text { dan kekerasan seksual, serta } \\
\text { sebagai bidan koordinator di } \\
\text { lingkungan Puskesmas yang } \\
\text { sering mengikuti pelatihan } \\
\text { KtP/A (lama bekerja } 25 \text { tahun). }\end{array}$ \\
\hline $\begin{array}{l}\text { Koordinator } \\
\text { Pelaksana } \\
\text { (KtP/A) }\end{array}$ & $\begin{array}{l}\text { Seorang perawat yang } \\
\text { bertugas sebagai } \\
\text { koordinator program Ktp/A } \\
\text { di Puskesmas. Sering } \\
\text { diikutkan pelatihan pada } \\
\text { program ini. (lama menjadi } \\
\text { koordinator } 5 \text { tahun) }\end{array}$ & $\begin{array}{l}\text { Perawat yang bertugas } \\
\text { sebagai pemangk program } \\
\text { KtP/A namun selama } \\
\text { Puskesmas berpindah } \\
\text { Tempat merasa tidak ada } \\
\text { Kasus KtP/A terjadi di } \\
\text { lingkungan Puskesmas (lama } \\
\text { menjadi koordinator } 3 \\
\text { tahun) }\end{array}$ & $\begin{array}{l}\text { Perawat bertugas sebagai } \\
\text { koordinator Program KtP/A di } \\
\text { Puskesmas. Sebagi pelapor } \\
\text { kasus kekerasan. (lama } \\
\text { menjadi koordinator } 6 \text { tahun) }\end{array}$ \\
\hline Psikolog & $\begin{array}{l}\text { Seorang psikolog yang baru } \\
3 \text { bulan bekerja di } \\
\text { Puskesmas. }\end{array}$ & $\begin{array}{l}\text { Tidak ada Psikolog } \\
\text { dikarenakan baru } \\
\text { pendidikan Polisi }\end{array}$ & $\begin{array}{l}\text { Psikolog yang bekerja di } \\
\text { lingkungan Puskesmas selama } \\
1.5 \text { tahun dan bertugas } \\
\text { sebagai tempat rujukan jika } \\
\text { terdapat kasus kekerasan. }\end{array}$ \\
\hline
\end{tabular}


Hasil penelitian ini menunjukkan bahwa target Pemerintah terhadap pendataan informasi baru sebatas pendataan kasus yang pernah terjadi. Puskesmas belum mampu dalam medeteksi masyarakat yang memiliki potensial terhadap kekerasan pada anak dan pemetaan daerah kasus KtP/A (Kemenkes RI, 2014).

Keterbatasan petugas Puskesmas dalam mengungkap wilayah yang potensial terjadi kekerasan dikarenakan tidak ada pelaporan dari masyarakat. Kader kesehatan yang perannya lebih dekat dengan petugas Puskesmas pun tidak tidak berperan dalam proses identifikasi kasus kekerasan pada anak. Kader dan masyarakat menganggap hal tersebut adalah wilayah domestik masing-masing keluarga.

"Kalau dari kader, memang jarang Bu. Rujukannya, memang susah kalau dari kader, biasanya mereka sudah kadang dianter sama polsek, atau dianter sama tetangganya mungkin itu, tapi mungkin kalau kader langsung sendiri kayanya jarang" (R1, W1).

"Beberapa kasus didapatkan dari pihak sekolah yang melaporkan anak didiknya mengalami kekerasan seksual" (N4, W1).

Hal ini sejalan dengan penelitan Fauziah (2010) yang menjelaskan bahwa wilayah binaan Puskesmas yang memiliki potensial kasus kekerasan yang tidak terungkap dikarenakan kasus kekerasan tersebut memang tidak dilaporkan, terutama apabila kasus kekerasan tersebut kasus kekerasan rumah tangga, yang merupakan urusan domestik dan tidak layak atau menjadi tabu jika diungkap ke masyarakat walaupun telah jelas diungkapkan bahwa pelaku kekerasan pada perempuan dan anak memiliki sanksi yang jelas. Joni dalam Maslihah (2013) menjelaskan dalam penelitiannya bahwa kasus kekerasan terutama kekerasan seksual seringkali masih ditutup-tutupi dan tidak diproses secara hukum karena melindungi nama baik keluarga.

Iskandar, Braun, dan Katz (2015) memberikan solusi terhadap permasalahan susahnya mengungkap kasus kekerasan khusunya pada perempuan. Solusi ini berupa screening kekerasan pada perempuan. Screening ini berasal dari Inggris dan memiliki reliabilitas dan validaitas yang baik dalam mendeteksi kekerasan pada perempuan terutama pada kekerasan dalam rumah tangga. Kekerasan pada anak bisa disebabkan oleh psikopatologi orang tua, yang berarti bahwa orang tua yang pernah menjadi korban kekerasan, memiliki riwayat dan sedang mengalami depresi, dan mengkonsumsi obat terlarang serta minuman beralkohol, memiliki perilaku antisosial, berkaitan dengan perilaku kekerasan yang dilakukan kepada anaknya (Petersen et al., 2014).

Sanksi yang ditetapkan pada kasus kekerasan yaitu berupa sanksi dunia yang diatur Pasal 81 dan 82 UU No. 23 Tahun 2002 tentang Perlindungan Anak bahkan mengancam pelakunya dengan hukuman yang lebih berat.

Selain itu Allah juga berfirman dalam surat QS. al-Isra ayat 31:

"Dan jangan kamu membunuh anak-anakmu karena takut miskin. Kami yang akan memberi rezeki kepada mereka dan juga kepadamu. Sesungguhnya membunuh mereka adalah suatu dosa yang besar."

Pada ayat di atas disebutkan bahwa Islam melarang membunuh anak-anak karena takut kemiskinan, sebelum datang Islam sendiri di komunitas Jahiliyah membunuh anak perempuan adalah sesuatu yang wajar. Kedatangan Islam memberikan angin segar, sebab Islam melarang 
tindakan yang berhubungan dengan kekerasan (IDI et al, 2004 dan Fauziah, 2010).

\section{Rencana kerja Puskesmas dalam penanganan kekerasan pada anak}

Puskesmas sebagai pusat kesehatan masyarakat terdekat sudah menerapkan pelayanan berbasis perlindungan anak, meliputi 1) Pihak Puskesmas menerapkan sistem non diskriminasi pada semua pasien, 2) pelayanan Puskesmas menjamin kelangsungan tumbuh kembang anak 3) pelauanan yang mementingkan keamanan (petugas yang berseragam, setiap pasien memiliki rekam medis yang berbeda, memiliki satpam, adanya informed concent dan informed choise, mengikuti sistem rujukan yang berlaku)

Dinas Kesehatan bekerja sama dengan pihak P2TP2A dalam penanganan KtP/A di lingkungan Puskesmas. Dari hasil wawancara didapatkan kekecewaan pihak P2TP2A yang menyatakan:

"Tidak semua Puskesmas itu peduli terhadap kasus kekerasan yang terjadi. Kasus kekerasan yang terjadi tidak dilaporkan ke pihak PTP2A dan hanya ditangani atau diobati luka luarnya. Jadi kami kesusahan dalam cek data antara Puskesmas, Dinas Kesehatan dan masyarakat. Sehingga terkesan sendiri-sendiri. Tidak terintegrasi" (P1, W1).

Rencana kerja Puskesmas dalam penanganan kekerasan pada Perempuan dan anak bukan merupkan rencana prioritas Puskesmas.

"Sebenarnya pelatihan memang ada Mbak, sudah disosialisasi juga, namun program ini mandeg dikarenakan bukan program kerja Puskesmas. Kami lebih ke arah penyakit menular seks" (R2, W1).

Kemenkes RI (2014) menjelaskan dalam pedoman pengembangan, Puskesmas mampu tatalaksana kasus kekerasan terhadap perempuan dan anak menjelaskan bahwa Puskesmas sebagai ujung tombak pelayanan kesehatan berperan dalam melaksanakan pelayanan kesehatan bagi korban KtP/A, untuk itu Puskesmas harus mampu dalam manajemen pengembangan Puskesmas mampu tatalaksana kasus KtP/A salah satunya dalam hal perencanaan, khususnya penyusunan rencana kerja terhadap penanganan kasus KtP/A. Namun, program ini tidak sesuai dengan hasil penelitian yang ada. Puskesmas belum menyusun rencana kerja terkait KtP/A karena bukan merupkan rencana prioritas Puskesmas. Pernyataan ini juga sejalan dengan keprihatinan pihak P2TP2A akan ketidaktahuan Puskesmas terhadap kasus yang terjadi di wilayah Puskesmas.

\section{Pelaksanaan sosialisasi kepada masyarakat dalam penaganan kekerasan pada anak}

Sebelum dilakukan sosialisasi ke masyarakat, pihak Puskesmas dalam hal ini koorditor program menyampaikan ke petugas Puskesmas dalam hal penanganan KtP/A.

"Biasanya seperti itu tapi kita ada sosialisasi, dapatnya sampai mana tiap kita pulang dari sana kita langsung sosialisasi. Kemarin itu kita sudah dapat satu, nanti berlanjut, nyambung. Gak pernah terputus kalau di sini. Karena kita sudah akreditasi, apapun kita semua ada laporannya. Jadi juga ada rencana tindak lanjutnya, jadi kita seiap akhir bulan kita selesai nanti kita langsung di rencana tindak lanjut sudah selesai belum teman-teman sosialisasi biasanya seperti itu" (R1, W1)

Sosialisasi terhadap KtP/A dilakukan oleh pihak Puskesmas berbarengan dengan kunjungan Puskesmas ke wilayah. 
"Biasanya kita dalam bentuk pertemuan ibu, biasanya, sosialisasikan ke kader, terus sama ke pertemuan-pertemuan yang berhubungan dengan tokoh masyarakat, itu, atau lintas sektor atau lintas program tetep kita sampaikan" (R1, W1).

Hasil penelitian menjelaskan bahwa sosialisasi dilaksanakan oleh tenaga kesehatan yang mendapatkan informasi ke petugas kesehatan lain di lingkungan Puskesmas kemudian disosialisasikan ke masyarakat. Namun demikian proses sosialisasi kegiatan pelaksanaan penanganan KtP/A di masyarakat tidak dilakukan secara khusus, namun diselipkan dalam program lain, sehingga bias memungkinkan kepekaan masyarakat tidak sepenuhnya muncul di benak masyarakat.

Penelitian sebelumnya yang dilakukan di Kabupaten Sleman Daerah Istimewa Yogyakarta, menyebutkan bahwa upaya yang dilakukan dalam peningkatan pemahaman masyarakat tentang perlindungan kekerasan yaitu dengan upaya sosialisasi. Sosialisasi yang dilakukan dengan berbagai metode baik secara berkelompok maupun langsung ke korban. Dari tindakan sosialisasi tersebut menimbulkan reksi positif dan negatif. Reaksi positif yang ditunjukkan masyarakat dengan adanya inisiatif masyarakat terhadap pelaporan kekerasan yang ada, dan menindaklanjuti kegiatan P2TP2A. Reaksi negatif yang ditunjukkan adalah kepasifan atau tidak pedulinya masyarakat akan kasus kekerasan yang ada di lingkungan sekitar (Agustina, 2016).

Sosialisasi yang dilakukan kepada masyarakat hendaknya dilakukan secara berkala dan selalu dilakukan monitoring dan evaluasi agar isi dari sosialisasi tepat sasaran dan dapat diimplementasikan oleh masyarakat. Sosialisasi yang dilaku- kan bisa berupa pelatihan kader terhadap pencegahan kasus. Penelitian terdahulu menyebutkan bahwa pelatihan mampu meningkatkan pengetahuan kader terhadap pencegahan kasus kekerasan seksual (Fariani \& Paramastri, 2015). Penelitian Nuzuliana dan Kenanga (2019) menjelaskan bahwa kader kesehatan mengetahui keberadaannya sebagai bagian dari masyarakat yang berperan aktif dalam kasus kekererasan pada anak. namun, kader tidak mengetahui bahwa Puskesmas mampu sebagai tempat pelaporan kasus kekerasan pada perempuan dan anak.

Kegiatan sosialisasi sesuai dengan agenda Program Kemenkes RI (2014) yaitu pihak Puskesmas yang terlatih atau yang telah mendapatkan proram penanganan KtP/A wajib melakukan sosialisasi internal yaitu lintas program Puskesmas dalam penyamaan persepsi dan peningkatan kepekaan petugas jika ada kasus kekerasan, kemudian sosialisasi langsung kepada masyarakat sasaran. Sarason dalam Anisa (2015) menjelaskan tujuan sosialisasi ini adalah tidak lain menumbuhkan dukungan sosial. Dengan dukungan sosial, keberadaan orang orang yang peduli, dan dapat diandalkan menjadikan korban kekerasan merasa terlindungi dan terkurangi beban dalam menghadapi kasus kekerasan pada dirinya. Kebijakan Pemerintah dalam upaya penanganan dan pencegahan kekerasan dalam rumah tangga dengan cara meningkatkan akses masyarakat terhadap pelayanan kekerasan pada masyarakat dengan program deteksi dini faktor risiko, pencegahan dan penanganan secara cepat dan terpadu (P2PTM Kementrian Kesehatan, 2012). 


\section{Sarana dan prasarana yang digunakan dalam penanganan kekerasan pada anak}

Tidak ada ruangan khusus yang disediakan Puskesmas dalam penanganan KtP/A. Dari ketiga Puskesmas, ruangan yang disediakan adalah ruangan Unit Gawat Darurat (UGD), Balai Pengobatan Umum (BPU), KIA (Kesehatan Ibu dan Anak), dan ruang psikolog. Kasus kekerasan ditangani sesuai dengan kekerasan yang terjadi.

"Begini Bu ... kami cuma ada ruang BPU, Psikolog, KIA, dan ruang perawat. Paling kalau ada kekerasan lansug dilihat, jika kehamilan tidak diinginkan kita rujuk ke KIA, jika butuh pengobatan kita rujuk ke BPU, jika butuh konsultasi kita ke psikolog" (N2, W1)

Hasil penelitian ini menujukkan bahwa dari ketiga Puskesmas masing-masing memiliki gedung Puskesmas dan memiliki alat komunikasi. Namun jika dilihat dari sarananya ketiga Puskesmas tidak memiliki ruangan khusus terhadap korban kekerasan. Hal ini tidak sejalan dengan Kemenkes RI (2009) menyebutkan, Puskesmas yang mampu dalam tatalaksana korban kekerasan pada perempuan dan anak harus memiliki prasarana berupa gedung Puskesmas, dan alat komunikasi.

Pelayanan kekekerasan pada anak berdasar penelitian ini masih dicampur dengan ruangan yang ada. Namun berdasarkan identifikasi, petugas kesehatan tetap menjamin kerahasiaan, keamanan dan kenyamanan pasien dengan cara menempatkan pasien di ruang yang sekiranya jauh dari akses publik. Form pencatatan dan pelaporan disediakan oleh Dinas Kesehatan yang diisi oleh petugas kesehatan di Puskesmas. Form tersebut harus dikumpulkan dan diisi sesuai dengan kejadian yang ada. Form tersebut berisi jenis kasus yang ada, identitas korban, ciri-ciri korban dan pelaku, bentuk kekerasan, tempat dan tanggal kejadian, jenis pelayanan yang diberikan. Sarana konseling/wawancara pada korban dilakukan secara manual, tidak menggunakan leaflet, brosur atau alat yang lain. Serta petugas kesehatan tidak merekam hasil wawancara yang dilakukan. Dari hasil pendataan petugas kesehatan tetap melaporan dalam formulir pendataan yang disediakan oleh Dinas Kesehatan. Kemenkes RI (2014) menyebutkan sarana yang harus ada di tempat pelayanan KtP/A meliputi ruangan yang khusus terhadap kasus pelayanan kekerasan pada anak secara tersendiri, menggunakan media konseling dan komunikasi, serta pencatatan dan pelaporan (Kemenkes Rl, 2014).

Sarana prasarana yang sesuai dengan standar akan menjadikan pelayanan kasus kekerasan lebih optimal. Sarana dan prasarana yang dibutuhkan di pihak Puskesmas adalah peralatan diagnosis klinis, sarana konseling dan wawancara (buku, lebar balik, perekam, alat permainan edukatif, kamera, formulir pencatatan) dan Standar Operasional Prosedur (Shartika et al., 2019).

\section{Pelaksanaan penanganan kekerasan pada anak yang dilakukan Puskesmas Kota Yogyakarta}

Penanganan KtP/A pada ketiga Puskesmas berupa pemeriksaan dan konseling.

"Sudah ada koordinasi. Nanti ke UGD dulu nanti biasanya kita ke sini (ke ruang KIA) tergantung yang dibutuhkan. Mungkin kalau untuk pemeriksaan kita pakai bed yang ada di sini (ruang KIA) terus kita cek karena kekerasan atau tidak, nanti secara sinkron nanti ada dokternya, ada saya (bidan) ada psikolognya, langsung kitatangani, nanti kita sering telpon karena ada pararel ada kasus satu ... gini gini, turun, nanti mereka turun ke bawah." 
Rujukan ke P2TP2A atau pihak yang terkait dilakukan oleh beberapa Puskesmas:

"Ya... apalagi, kita sering kerjasama di apa, yang ada di Badran itu, (ya ... PKBI), jadi kalau ada kasus, mungkin lebih cepat ditangani, mungkin kalau kita tidak bisa langsung kita rujuk kesana. karena kalau misalnya gangguan psikis, mereka dilindungi, karena misalnya, dia sangat trauma, takut, ada ancaman ... Biasanya kita damping ibu jangan sampai melakukan tindakan yang tidak dinginkan, biasanya itu mereka kerjasama dari lingkungan, dari masyarakat, itu sudah bareng, dari lintas sektoralnya kita sudah sama. Sampai Dinas Sosial juga" (R1, W1).

Pelaksanaan kasus KtP/A pada ketiga Puskesmas berupa pemeriksaan dan dan konseling. Hal ini sesuai dengan arahan Kemenkes RI (2014) yang menyebutkan bahwa pelaksanaan tindakan kasus KtP/A yang dilakukan Puskesmas dalam hal pemeriksaan kesehatan berupa anamnesa wawancara, konseling dan pemeriksaan umum serta pelaksanaan pemeriksaan penunjang berupa pemeriksaan Rontgen dan laboratorium. Namun demikian dari ketiga Puskesmas tidak melakukan pemeriksaan Rontgen karena tidak memiliki sarananya.

Kegiatan penanganan kasus KtP/A perlu tindakan penanganan yang melibatkan Interprofesional Colaboration. Puskesmas menangani kekerasan dalam langkah dan tindakan awal meliputi perawaan luka, reposisifraktur, stabilisasi perawatan, pemberian nutrisi. Pencaatan dan pelaporan, Pembuatan visum et repertum atas permintaan Polisi. Untuk melakukan rujukan perlu dipersiapkan: surat pengantar rujukan, kronologis singkat kasus dan bukti-bukti yang mendukung (pakaian, celana dalam, rambut pubis, kotoran/ debris pada kuku, swab vagina, dan lain-lain
(Peraturan Menteri Kesehatan Republik Indonesia Nomor 68 Tahun 2013).

Monitoring dilakukan pihak Puskesmas untuk kasus yang masuk di Puskesmas. Dua dari Puskesmas yang diteliti menyebutkan bahwa kasus kekerasan jarang terjadi sehingga monitoring dan evaluasi tidak dilakukan. Monitoring hanya berupa pelaporan yang dilakukan Puskesmas ke Dinas Kesehatan Kota Yogyakarta.

“Pelaporan kasus kekerasan kepada pihak berwajib diserahkan kepada korban Kemarin ada kasus kekerasan yang datang ke Puskesmas, lebam di area muka, terus kita tanyakan, ibunya bilang kalau dipukul suaminya. Kemudian kita tawarkan ini divisum saja ya Bu ... ternyata korban enggan dilakukan visum. Ya saya tidak bisa memaksa, apalagi kalau korban itu hanya ibu rumah tangga ... biasanya mereka mikir, nanti yang membiayai siapa kalau bapakanya dilaporkan" (N2, W1).

Pelaporan Kasus kekerasan pada perempuan dan anak dilaporkan pihak Puskesmas ke Dinas Kesehatan Kota Yogyakarta. System pelaporan berdasarkan Form Yang telah disediakan oleh Dinas Kesehatan. Pelaporan berbentuk soft file yang dikirim secara email dan hard copy yang dikirim langsung ke pihak Dinas Kesehatan. Pelaporan dilakukan setiap awal bulan.

Kemenkes RI (2014) menjelaskan monitoring dan evaluasi (monev) pelayanan KtP/A dilakukan oleh kepala Puskesmas kepada staf melalui pembinaan dan pendampingan, lokakarya dan rapat bulanan Puskesmas. Dasar dari pelaksanaan monev ini adalah data dari pelporan kasus yang ditemukan oleh staf pada elayanan kasus KtP/A. Hasil Monev dapat digunakan sebagai perbaikan langkah selanjutnya apabila ditemukan ketidak sesuaian di lapangan. 
Monitoring dan evaluasi yang dilakukan secara continue dan sungguh sungguh akan menegaskan komitmen Puskesmas dalam menyuarakan hak perempuan dan anak, dan akan menjadikan wilayah ramah perempuan dan anak dan pemenuhan penyelenggaraan perlindungan perempuan dan anak terpenuhi (Shartika et al., 2019). Tindak kekerasan yang terjadi bisa dikendalikan dan dicegah dengan upaya promotiv dan preventif. Upaya tersebut meliputi pengembangan pola asuh dan hubungan yang baik antara orang tua dan anak, mengembangkan life skills pada anak dan remaja (WHO 2009 dalam P2PTM Kementrian Kesehatan, 2012).

\section{Kesimpulan}

Dari hasil data dan informasi terhadap KtP/A dari ketiga Puskesmas data paling banyak didapatkan dengan cara korban datang langsung ke Puskesmas dan pihak Puskesmas jarang melakukan identifikasi atau deteksi dini kasus kekerasan di wilayah. 2) Rencana kerja Puskesmas dalam penanganan kekerasan pada Perempuan dan anak bukan merupakan rencana prioritas Puskesmas.

Sosialisasi yang dilakukan pihak Puskesmas yaitu sosialisasi intern dan eksternal. Sosialisasi eksternal di lakukan berbarengan dengan program Puskesmas yang lain.

Sarana prasarana yang dimiliki Puskesmas adalah gedung, ala komunikasi, ruang pemeriksaan yang disediakan tidak secara khusus unutk kasus kekerasan (namun jika ada kasus privasi pasien tetap terjaga), dan dokumen pelaporan kasus kekerasan pada anak dan perempuan.
Pelaksanaan penanangan kekerasan pada anak berupa periksaan fisik, konseling, monitoring dan evaluasi yang dilakukan pihak Puskesmas sekedar pencatatan dan pelaporan yang disiapkan untuk pelaporan ke Dinas Kesehatan.[]

\section{Daftar Pustaka}

Agustina, A. (2016). Upaya Pusat Pelayanan Terpadu Perlindungan Perempuan dan Anak (P2TP2A) Kabupaten Sleman dalam memberikan perlindungan anak terhadap kekerasan [Universitas Negeri Yogyakarta]. https://eprints.uny.ac.id/34041/

Amiruddin, M., Tardi, S. A., Hutabarat, R., \& Ratnawati, R. (2020). Siaran pers Komnas Perempuan. Catatan tahunan kekerasan terhadap perempuan 2019. Kekerasan meningkat: Kebijakan penghapusan kekerasan seksual untuk membangun ruang aman bagi perempuan dan anak perempuan. https:// komnasperempuan.go.id/pengumumandetail/siaran-pers-dan-lembar-fakta-komnasperempuan-cata

Anisa, F., Nurjannah, I., \& Widyawati, W. (2015). Identifikasi diagnosa keperawatan dan masalah kolaborasi pada remaja korban kekerasan seksual pada Domain 6 dan 9 Nanda Taxonomy dengan menggunakan 6 Steps Method in Diagnostic [Universitas Gadjah Mada]. http://etd.repository.ugm.ac.id/penelitian/de tail/86072

BPPM DIY. (2016). Peta kekerasan terhadap perempuan dan anak di Kota Yogyakarta. Badan Pemberdayaan Perempuan dan Masyarakat.

Fariani, A., \& Paramastri, I. (2015). Kader Posyandu sebagai agen pencegahan primer tindakan kekerasan seksual pada anak. Gadjah Mada 
Journal of Professional Psychology, 1(2), 138149. https://doi.org/10.22146/gamajpp.9215

Fauziah, D., \& Syamsiyatun, S. (2010). Perlindungan anak korban kekerasan dalam keluarga (Studi kasus terhadap penanganan anak korban kekerasan dalam keluarga di Lembaga Perlindungan Anak Provinsi DIY). Universitas Islam Negeri Sunan Kalijaga Yogyakarta.

IDI, Depkes-RI, \& UNICEF. (2004). Buku pedoman pelatihan deteksi dini dan penatalaksanaan korban child abuse and neglect bagi tenaga profesional.

Iskandar, L., Braun, K. L., \& Katz, A. R. (2015). Testing the woman abuse screening tool to identify intimate partner violence in Indonesia. Journal of Interpersonal Violence, 30(7), 1208-1225. https://doi.org/10.1177/0886260514539844

Ismiyanto, A., \& Nugroho, A. (2019, August 6). LPSK catat 60 kasus kekerasan pada perempuan dan anak di DIY. Tribunjogja.Com. https://jogja.tribunnews.com/2019/08/06/lp sk-catat-60-kasus-kekerasan-padaperempuan-dan-anak-di-diy

Kemenkes Rl. (2009). Pedoman Pengembangan Puskesmas Mampu Tatalaksana Kasus Kekerasan terhadap Perempuan dan Anak. Jakarta: Sekretaris Direktorat Jenderal Bina Kesehatan Masyarakat Kementerian Kesehatan Republik Indonesia.

Kemenkes Rl. (2014). Pedoman pengembangan Puskesmas mampu tatalaksana kasus kekerasan terhadap perempuan dan anak. Jakarta: Sekretaris Direktorat Jenderal Bina Kesehatan Masyarakat Kementerian Kesehatan Republik Indonesia.

Komnas Perempuan. (2017). Labirin Kekerasan terhadap Perempuan: Dari Gang Rape hingga Femicide, Alarm bagi Negara untuk Bertindak Tepat. Lembar Fakta Catatan Tahunan (CATAHU) Komnas Perempuan Tahun 2017, 1-4.
KPAl. (2016). Data kasus perlindungan anak tahun 2011-2016. Jakarta: Komisi Perlindungan Anak Indonesia.

KPAl. (2020). Rincian tabel data kasus pengaduan anak berdasarkan kluster perlindungan anak Komisi Perlindungan Anak (KPAl).

Maslihah, S. (2013). Play therapy dalam identifikasi kasus kekerasan seksual terhadap anak. Jurnal Penelitian Psikologi, 4(1), 21-34.

Moerti, W. (2019, December 31). Data KPAl, selama 2019 ada 123 anak korban kekerasan seksual di institusi pendidikan. Merdeka.Com. https://www.merdeka.com/peristiwa/datakpai-selama-2019-ada-123-anak-korbankekerasan-seksual-di-institusipendidikan.html\#: :text=Kontak Kebijakan Privasi-,Data KPAl\%2C Selama 2019 Ada 123 Anak,Kekerasan Seksual di Institusi Pendidikan\&text=Merdeka.com - Komisi Perlindungan Anak,yang terjadi di institusi pendidikan.

Nuzuliana, R., \& Ma'rifat, D. K. (2019). Pengetahuan kader tentang kekerasan pada anak. Profesi (Profesional Islam): Media Publikasi Penelitian, 16(2), 90-96. https://doi.org/10.26576/ profesi.327

P2PTM Kementrian Kesehatan. (2012). Pedoman pengendalian kekerasan dalam rumah tangga. Jakarta: Kementerian Kesehatan Republik Indonesia.

Petersen, A. C., Joseph, J., \& Feit, M. (2014). New directions in child abuse and neglect research. Washington, D.C.: National Academies Press. https://doi.org/10.17226/18331

Shartika, N. P., Yetti, H., \& Yusda, I. (2019). Analisis penyelenggaraan Puskesmas tatalaksana kekerasan terhadap anak (KtA) dalam penanganan kekerasan anak di Kota Padang. Jurnal Kesehatan Andalas, 8(2), 245-253. https://doi.org/10.25077/jka.v8i2.998 
This page itentionally left blank. 